\title{
DIÁLOGOS COM O TEATRO POPULAR NO NORDESTE
}

\author{
por Joana Abreu Oliveira*
}

CAMAROTTI, Marco. Resistência e voz: o teatro do povo do Nordeste. Recife: Ed. Universitária da UFPE, 2001. 313 p.

Embora seja possível encontrar uma profusão de manifestações folclóricas no Brasil e especialmente no Nordeste do país, poucos são os estudos aprofundados a esse respeito. É, entre outras coisas, com o intuito de diminuir tal lacuna no que toca ao Teatro Folclórico Nordestino, que o professor, ator e encenador pernambucano Marco Camarotti apresenta suas investigações no livro Resistência e voz: $o$ teatro do povo do Nordeste. Tais investigações giram em torno da origem, das características e do sentido contemporâneo de quatro formas de teatro folclórico representadas no Nordeste do país: o Bumba-meu-boi, a Chegança, o Pastoril e o Mamulengo. Tais formas foram escolhidas por serem, em sua opinião, as que apresentam estrutura dramática mais claramente definida.

A hipótese do autor é que tais manifestações são não apenas restos dos rituais religiosos pré-históricos, como apontam algumas correntes de estudo, mas expressão de relações sociais e políticas. Tal hipótese faz com que Camarotti busque o diálogo com disciplinas como a Antropologia Social e a Sociologia da Arte, a fim de construir uma metodologia adequada para desenvolver suas reflexões e chegar a algumas conclusões. Com o intuito de fundamentar as idéias expostas, na primeira parte do livro, o leitor tem a possibilidade de entrar em contato com informações bem completas a respeito das conexões entre teatro, ritual e teatro folclórico.

* Mestranda em Arte na UnB, atriz e arte-educadora. 
A habilidade em tecer relações e diálogos entre autores e correntes de pensamento preocupados com o objeto em questão é um dos méritos do livro que traz ainda um cuidadoso levantamento do histórico e dos símbolos envolvidos em cada uma das quatro formas teatrais escolhidas. Em relação a essa reunião de símbolos, é possível que a obra seja uma das referências mais completas da atualidade, especialmente por trazer a contribuição de questionar a situação de muitos desses símbolos em nossa contemporaneidade. Referência tão abrangente e cuidadosa talvez deixe o leitor desejoso de que alguns símbolos citados fossem mais profundamente explorados.

É importante ressaltar que essa abrangência da pesquisa dáse em relação à maneira como tais manifestações são realizadas em Pernambuco. Embora o autor cite, entre outros, exemplos do Bumbameu-boi do Maranhão ou da Chegança da Paraíba, esses surgem apenas no sentido de possibilitar uma visão mais clara da maneira como o folguedo se manifesta em Pernambuco. Isso é bastante compreensível se pensarmos que seria necessário outro estudo, talvez do mesmo porte, para abarcar as especificidades das manifestações em cada um dos outros Estados em que ainda existem, e, certamente, não era essa a intenção do autor.

Para os estudiosos do assunto, o volume apresenta bibliografia bastante completa. Com grande parte dos autores citados, tais como Augusto Boal, Mário de Andrade, Metín And, Câmara Cascudo, Oswald Barroso, Hermilo Borba Filho, Ascenso Ferreira, Peter Burke, Fernando Augusto Gonçalves Santos, o diálogo do texto é bastante preciso, apoiando-se em muito do que já foi dito anteriormente e alçando assim saltos que vão um pouco além. Um arcabouço tão consistente de referências, contudo, faz-nos sentir falta, em alguns momentos, de conexões mais abrangentes com obras como a de Mikhail Bakhtin. Embora citado, talvez esse autor pudesse contribuir mais, principalmente se pensarmos na opção de Marco Camarotti de ressaltar e iluminar o caráter do folguedo como "um potente canal de comunicação" (p. 174) para as comunidades, bem como elemento de expressão da voz desses grupos sociais. Tal contribuição poderia estender-se também para outra característica do folguedo explorada: 
o cômico, o grotesco e o obsceno como instrumento de crítica e compreensão da realidade.

Para os estudos da performance, as contribuições de Resistência e voz: o teatro do povo do Nordeste são consideráveis, já que explicita diversos elementos presentes no Teatro Folclórico do Nordeste que são fundamentais para qualquer teatro, mostrando, embora não explicitamente, que o Teatro Folclórico pode ser uma referência nos processos de estudo e formação para o teatro brasileiro em geral. Entre esses elementos estão o uso da improvisação e a ampla participação dos espectadores.

Os fatores do contexto social e histórico presentes nos quatro folguedos explorados são bem ressaltados. Isso se explicita, por exemplo, na reflexão sobre "noções como 'autenticidade', 'identidade' e 'raízes"” que, para Camarotti, "são idéias típicas de culturas pós-coloniais que necessitam elaborar sinais que possam reafirmar e enfatizar suas novas condições de nações independentes" (p. 69). Comentário similar é tecido quando se trata das relações de classes, presentes na luta entre opressor e oprimido que se revela nos enredos do teatro de mamulengo ou, mais subrepticiamente, na sugestão de que os conflitos entre mouros e cristãos presentes nas encenações seriam, atualmente, menos um símbolo da luta religiosa e mais o reflexo das lutas sociais. Essas mesmas lutas sociais poderiam estar fortemente relacionadas com a histórica repressão aos folguedos, sendo os espetáculos do Teatro Folclórico do Nordeste vistos "como uma espécie de ameaça por aqueles que não estão interessados na tomada de consciência do povo e no seu conseqüente fortalecimento como uma massa dotada de voz e vontade próprias" (p. 154). Essa visão ameaçadora deve-se ao fato do teatro, embora não mais carregado da função religiosa propriamente dita, ser uma experiência mágica, de transformação, que reforça a cosmologia coletiva "ajudando as pessoas não só a tomarem consciência da estrutura social e de sua posição dentro dela, mas também a reagirem adequadamente diante de cada situação em particular” (p. 174). 
Outro elemento do contexto social ressaltado é a reduzida participação das mulheres na maioria dos folguedos ao longo da história. Possíveis explicações oferecidas por diferentes pesquisadores são mencionadas para justificar tal situação, além de ser citado o fato de, na atualidade, tal realidade estar se modificando bastante. Entretanto, ainda que as mulheres sejam mencionadas várias vezes, fica a impressão de uma visão masculina das mesmas. Falta dar voz a essa figura feminina, não só no próprio folguedo, mas também nas pesquisas.

Na prosa bem construída do livro de Camarotti, trazer à tona tantos elementos do contexto social tem objetivo muito claro. Toda a reflexão do autor se conduz para um fim de estabelecimento de relações entre o Teatro Folclórico do Nordeste e seu Contexto Social para, a seguir, aproximar-se da noção de Drama Social. A fim de empreender essa tarefa, é elaborada uma metodologia específica, apoiada em autores como Mary Douglas, Basil Bernstein, Elaine Turner, Richard Schechner, Victor Turner e Carlo Ginzburg. Assim, Marco Camarotti parte da dinâmica na relação entre indivíduo e sociedade para investigar de que maneira tal dinâmica atua na manutenção e na renovação da cosmologia de cada grupo social, entendendo ainda que é justamente nessa dinâmica de tensões entre o universo do sujeito e o do grupo social que é conferido o significado à pessoa e às suas ações.

Camarotti procura conectar tais idéias à proposição sociolingüística de Bernstein, que afirma que as formas sociais irão atuar no discurso do indivíduo, o qual, por sua vez, acabará por reorganizar essas próprias práticas sociais. Contribui ainda para tal metodologia a visão de Turner, que sublinha o caráter dinâmico e sempre em construção das estruturas sociais, bem como seu conceito de Drama Social como unidade de um processo social desarmônico suscitado em situação de conflito.

A partir de todas essas ferramentas, o autor explicita o forte papel social de tais manifestações e o poder de comunicação de seus símbolos, inferindo, conseqüentemente, que há poucas possibilidades 
de que tal teatro deixe de existir, mas sim que permaneça e se renove, se adapte, se transforme. Embora a proposta seja bastante interessante e ainda que as ferramentas utilizadas tenham consistência, talvez valesse a pena debruçar-se mais lentamente sobre cada uma delas, bem como sobre as relações estabelecidas entre as mesmas. O próprio autor menciona, na introdução, o fato de o estabelecimento de uma metodologia consistente não ter sido plenamente atingido.

Finalmente, talvez fosse uma contribuição valiosa para o material reunido se pudéssemos nos deparar mais vezes com as vozes dos próprios artistas do Teatro Folclórico a respeito de seu fazer. Passagens como aquela em que Camarotti cita o Capitão Antonio Pereira dizendo que "sem dúvida, esse bumba-meu-boi parece ser uma coisa que ajuda a humanidade inteira" dão um brilho especial à proposta.

Por outro lado, Marco Camarotti alcança com destreza a meta central de fazer um levantamento bastante completo e significativo de informações sobre a situação das quatro formas de Teatro Folclórico escolhidas. Num texto prazeroso e pleno de dados e informações consistentes, o autor não se limita a registrar tamanha riqueza de nossa tradição oral, mas possibilita ao leitor a profunda reflexão sobre o papel que as formas de Teatro Folclórico ocupam e podem vir a ocupar no Nordeste e no mundo. 